\title{
INVESTIGATIONS ON PROCESSING OF CEMENTED CARBIDES AND COMPOSITE MATERIALS (BNDCC AND DDCC) BY MEANS OF GRINDING AND HYBRID MACHINING
}

\author{
BADANIA PROCESU KSZTAŁTOWANIA WĘGLIKÓW SPIEKANYCH \\ I MATERIAŁÓW KOMPOZYTOWYCH (BNDCC I DDCC) \\ PRZEZ SZLIFOWANIE ORAZ Z WYKORZYSTANIEM \\ HYBRYDOWYCH METOD OBRÓBKI
}

\author{
Grzegorz SKRABALAK ${ }^{1}$, Barbara STANIEWICZ-BRUDNIK ${ }^{1}$, \\ Elżbieta BĄCZEK ${ }^{1}$, Andrzej STWORA ${ }^{1}$
}

\begin{abstract}
The paper presents analysis of influence of parameters and conditions of grinding process using diamond grinding wheels with ceramic bond (Ba23 bis, W1) on the geometrical structure and quality of machined cemented carbides (H10S) and composite materials (BNDCC). During performed analyses there was calculated the material removal rate Qw, specific material removal rate Q'w and G coefficient. There was performed comparative analyses of achieved results for various materials. There is also presented influence of machining conditions on the material removal process efficiency and quality of surface after machining of composite materials (DDCC and BNDCC) when using non-conventional machining processes: electrodischarge wire cutting (WEDM), electrochemical machining with rotating tool electrode (RECM) and hybrid process of electrochemical-electrodischarge machining with rotating tool (R-ECDM) with grinding wheel and metal disk as the tool electrode.
\end{abstract}

Keywords: cemented carbides, composite material, grinding, grinding parameters, geometrical structure of surface, hybrid machining, electrodischarge wire cutting, electrochemical machining with rotating tool

Streszczenie: W artykule przeanalizowano wpływ parametrów i warunków obróbki szlifowaniem ściernicami diamentowymi ze spoiwem ceramicznym (Ba23 bis, W1) na strukturę geometryczną powierzchni węglików spiekanych H10S oraz kompozytów (BNDCC). Topografię powierzchni obrabianej określono poprzez parametry wysokościowe, horyzontalne, obraz 2D i 3D. Obliczono wydajność ubytkową szlifowania Qw, właściwą wydajność ubytkową szlifowania Q'w oraz syntetyczny wskaźnik szlifowania G. Przeprowadzono analizę porównawczą uzyskanych wyników.

\footnotetext{
${ }^{1}$ The Institute of Advanced Manufacturing Technology, Wrocławska 37a, 30-011 Kraków
} 
Zaprezentowano również wpływ warunków obróbki na wydajność procesu oraz jakość powierzchni po obróbce kompozytów DDCC i BNDCC przy użyciu hybrydowej technologii obróbki elektrochemiczno-elektroerozyjnej (z tarczą ścierną oraz dyskiem metalowym jako elektrodami roboczymi).

Słowa kluczowe: węgliki spiekane, materiał kompozytowy, szlifowanie, parametry szlifowania, struktura geometryczna powierzchni, obróbka hybrydowa, obróbka elektroerozyjna elektrodą drutową, obróbka elektrochemiczna narzędziem obrotowym

\section{INTRODUCTION}

Modern materials and need for fast and low-loss manufacturing of parts, especially in automotive and aerospace sectors, require cutting tools with high performance characteristics. Currently developed materials used for production of cutting tools are often of high hardness and the same difficult to shape effectively with precision. Presented study concerns comparison of shaping various materials used for cutting tools using conventional grinding process with hybrid electrochemical-electrodischarge machining with rotating tool electrode. Among materials being subject to presented research are composite materials BNDCC (Boron Nitride Dispersed Cemented Carbide), DDCC (Diamond Dispersed Cemented Carbide) and cemented carbides (used as the reference material). Samples of composite materials used for the test purposes were prepared using cubic boron nitride (BNDCC) and diamond (DDCC) grains of size $6-12 \mu \mathrm{m}$ [1]. In both cases concentration of superhard grains in cemented carbide was $20 \%$ (weight of materials before sintering). Sample SEM micrograph of BNDCC composite is presented in Figure 1.

Cutting tools made of BNDCC and DDCC composite materials are used in the automotive industry for machining of pistons and engine components made of aluminum alloys and cast iron with high cutting speeds and minimum quantity lubrication. Therefore preparing cutting tools of high precision and high quality surface is important.

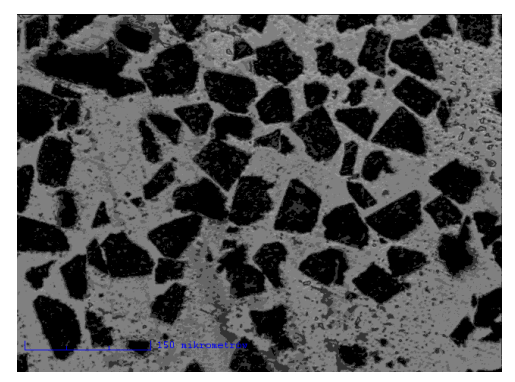

Figure 1. SEM micrograph of BNDCC composite material (dark spots are $\mathrm{cBN}$ grains)

\section{CONVENTIONAL GRINDING}

\subsection{EXPERIMENT SETUP}

For the needs of effective and high quality grinding process of composite materials with embedded superhard grains, new type of binder for grinding wheels was developed [2]. The vitrified bond belonging the group of light, characterized by a low density (ranging between 
2.34-2.69 $\mathrm{g} / \mathrm{cm}^{3}$ ) was used for preparing grinding wheel. Tests were performed using wheels 6A2 $100 \times 10 \times 4 \mathrm{~mm}$ type, containing uncoated diamond grain, Lands LS120 (D46-45-38 microns) type or LS 600F (D25-20-30 microns) with higher concentration of diamond $(\mathrm{C} 125 \%)$ and a W1 or Ba23 bis binder (Fig. 2a,b). Detailed characteristics of binder used for production of grinding wheels is described in Table 1 [3].

Table 1. Properties of developer binder used for production of grinding wheels

\begin{tabular}{|c|c|c|c|c|c|c|}
\hline Type & $\begin{array}{c}\text { Density } \\
{\left[\mathrm{g} / \mathrm{cm}^{3}\right]}\end{array}$ & $\begin{array}{c}\text { Bending } \\
\text { strength } \\
{[\mathrm{MPa}]}\end{array}$ & $\begin{array}{c}\text { Work of } \\
\text { destruction } \\
{[\mathrm{N} / \mathrm{mm}]}\end{array}$ & $\begin{array}{c}\text { Bending } \\
\text { modulus } \\
{[\mathrm{GPa}]}\end{array}$ & $\begin{array}{c}\text { Poisson's } \\
\text { ratio }\end{array}$ & $\begin{array}{c}\text { Young } \\
\text { modulus } \\
{[\mathrm{GPa}]}\end{array}$ \\
\hline $\mathrm{W} 1$ & 2.4548 & $105.72 \pm 2$ & 19.27 & 25.945 & 0.38 & 79 \\
\hline Ba 23 bis & 2.6912 & 101.35 & 16.49 & 27.195 & 0.38 & 87 \\
\hline
\end{tabular}

Tests were carried out using tool grinder (Fig. 2c), equipped with smooth speed control of the wheel and the cooling system. During experiments, coolant (2\% solution of PGA Synkon coolant concentrate dissolved in tap water) was supplied to the working area.
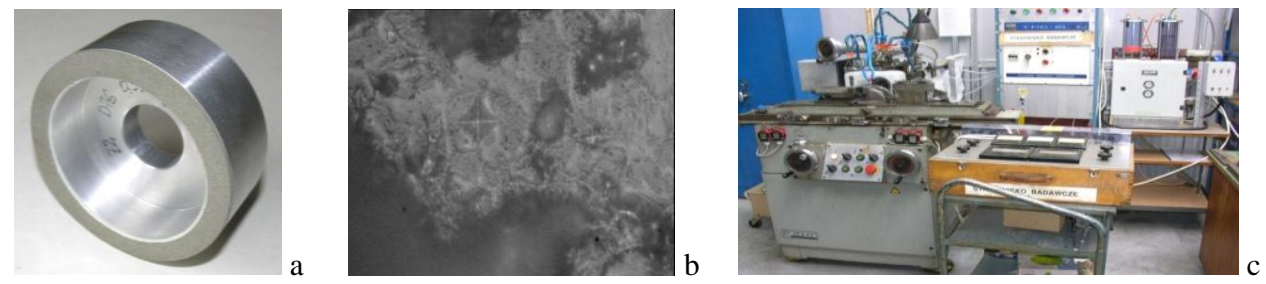

Figure 2. Grinding wheel (a) and its SEM micrograph (b) used for experiments, test stand (c)

Experiments were conducted according to the plan of experiments with investigated parameters as following:

- grinding wheel peripheral speed, $\mathrm{V}_{\mathrm{s}}=12,15,20 \mathrm{~m} / \mathrm{s}$;

- working engagement $\mathrm{a}_{\mathrm{e}}$ 0.002, 0.005, $0.01 \mathrm{~mm} /$ double stroke of the table;

- diamond grain D46, D25.

During investigations constant parameters were:

- table feed speed: $\mathrm{V}_{\mathrm{f}}=210 \mathrm{~mm} / \mathrm{min}$;

- machining time of one cycle: $t=600 \mathrm{~s}$;

- number of table double strokes: 3.

\subsection{RESULTS OF GRINDING PROCESS}

After performed experiments, surface roughness of machined elements was measured. Basing on the measurement of amount of removed material from the samples, there were also calculated factors characterizing performance of grinding process: material removal rate $\left(\mathrm{mm}^{3} / \mathrm{s}\right)$, specific material removal rate $\left(\mathrm{mm}^{3} / \mathrm{mm}^{*} \mathrm{~s}\right)$ and $\mathrm{G}$ ratio. Results of machining of cemented carbide (H10s) are presented in Figure 3 and Table 2 below. 


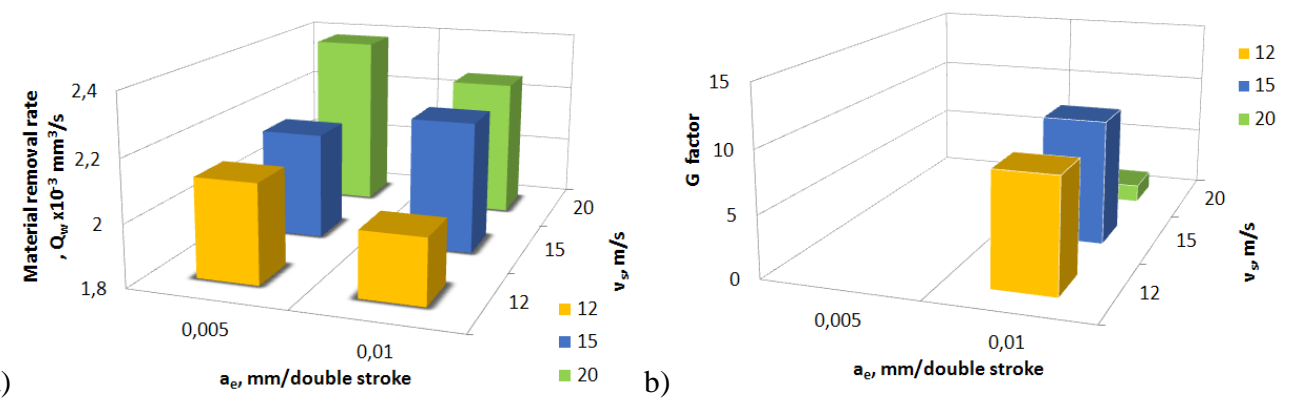

Figure 3. Results of grinding cemented carbide (H10s) with D46 Ba 23 bis grinding wheel: material removal rate (a), $\mathrm{G}$ factor (b)

Table 2. Results of grinding cemented carbide (H10s) with D46 Ba 23 bis grinding wheel

\begin{tabular}{|c|c|c|c|c|}
\hline $\begin{array}{c}\mathrm{V}_{\mathrm{s}}, \\
\mathrm{m} / \mathrm{s}\end{array}$ & $\mathrm{a}_{\mathrm{e}}, \mathrm{mm} / \mathrm{double}$ stroke & $\begin{array}{c}\mathrm{Q}_{\mathrm{w}}, \mathrm{x} 10^{-3} \\
\mathrm{~mm}^{3} / \mathrm{s}\end{array}$ & $\begin{array}{c}\mathrm{Q}^{\prime}{ }_{\mathrm{w}}, \mathrm{x} 10^{-3} \\
\mathrm{~mm}^{3} / \mathrm{mm} \cdot \mathrm{s}\end{array}$ & $\mathrm{G}$ \\
\hline \multirow{2}{*}{12} & 0.005 & 2.12 & 0.21 & 9.12 \\
\cline { 2 - 5 } & 0.01 & 2.01 & 0.2 & 10.14 \\
\hline \multirow{2}{*}{15} & 0.005 & 2.15 & 0.21 & \\
\hline \multirow{2}{*}{20} & 0.01 & 2.23 & 0.22 & 1.44 \\
\cline { 2 - 5 } & 0.005 & 2.38 & 0.24 & \\
\hline
\end{tabular}

After grinding process also surface roughness of machined samples was measured. In case of machining of cemented carbide with D46 Ba 23 Bis grinding wheel surface roughness did not change significantly with change of grinding speed. Averaged measured roughness was as follows:

$$
\begin{aligned}
& \mathrm{R}_{\mathrm{a}}=0,017 \mu \mathrm{m}( \pm 0,001) ; \\
& \mathrm{R}_{\mathrm{a}}=0,111 \mu \mathrm{m}( \pm 0,009) .
\end{aligned}
$$

Grinding tests were also performed for samples prepared of BNDCC composite materials. Selected results of these experiments are presented in Table 3.

Table 3. Results of grinding BNDCC composite with D46 Ba 23 bis grinding wheel

\begin{tabular}{|c|c|c|c|c|}
\hline \multirow{2}{*}{$\mathrm{V}_{\mathrm{s}}, \mathrm{m} / \mathrm{s}$} & $\mathrm{a}_{\mathrm{e}}, \mathrm{mm} /$ double stroke & $\mathrm{Q}_{\mathrm{w}}, \times 10^{-3} \mathrm{~mm}^{3} / \mathrm{s}$ & $\mathrm{Q}_{\mathrm{w}}^{\prime}, \times 10^{-3} \mathrm{~mm}^{3} / \mathrm{mm} \cdot \mathrm{s}$ & $\mathrm{G}$ \\
\hline \multirow{2}{*}{12} & 0.002 & 1.35 & 0.14 & 3.41 \\
\cline { 2 - 5 } & 0.005 & 1.27 & 0.13 & 5.88 \\
\hline \multirow{2}{*}{15} & 0.002 & 2.29 & 0.23 & 29.48 \\
\cline { 2 - 5 } & 0.005 & 2.23 & 0.22 & 26.94 \\
\hline \multirow{2}{*}{20} & 0.002 & 1.31 & 0.13 & 17.91 \\
\hline
\end{tabular}

Also in case of machining of BNDCC composite materials, surface roughness of machined samples was measured. Similar to machining of cemented carbide with D46 Ba 23 Bis 
grinding wheel, also in case of BNDCC sample, there was not significant influence of grinding speed on surface roughness. Averaged measured roughness was as follows:

$$
\begin{aligned}
& \mathrm{R}_{\mathrm{a}}=0,017 \mu \mathrm{m}( \pm 0,003) ; \\
& \mathrm{R}_{\mathrm{a}}=0,071 \mu \mathrm{m}( \pm 0,060) .
\end{aligned}
$$

\subsection{RESULTS OF GRINDING PROCESS - DISCUSSION}

Results of machining cemented carbide and BNDCC composite were compared for the same tools (grinding wheels) and machining conditions (Fig. 4). It can be observed that better efficiency of material removal rate is for composite material with dispersed superhard grains. Presence of hard grains $(\mathrm{cBN})$ in the structure of grounded material might have positive effect on in-situ sharpening if wheel, as well as preventing grinding wheel from clogging with cemented carbides. This phenomena does not occur in case of machining pure cemented carbides.
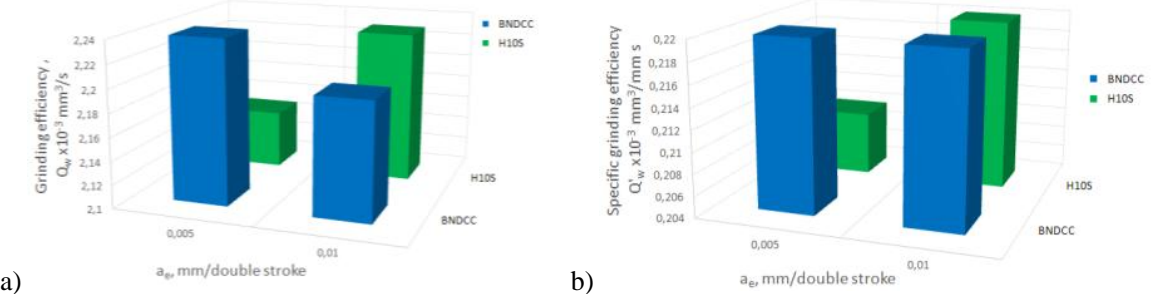

a)

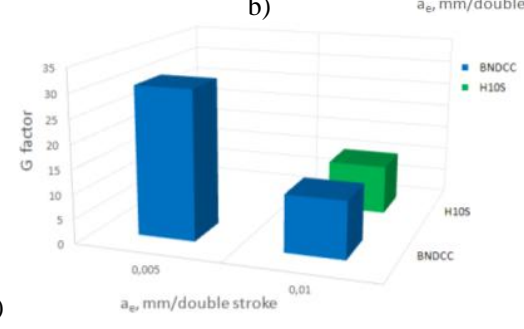

Figure 4. Comparison of grinding efficiency (a), specific grinding efficiency (b) and $\mathrm{G}$ factor (c) of grinding of BNDCC composite and cemented carbide H10S

\section{ELECTROCHEMICAL DISCHARGE MACHINING (ECDM)}

Electrochemical Discharge Machining (ECDM) using pulse voltage and is the hybrid methods of machining involving electrochemical dissolution (ECM) and electrodischarge machining (EDM). The process yields rates of material removal that can be as much as five to fifty times greater than ECM and EDM respectively [4-6]. Main applications in which a combined form of both processes has been used concern hole drilling, die sinking, and cutting. Effective means of improving ECDM accuracy and smoothing is imparting a rotating movement to the profile-shaped wheel-electrode. Figure 5a shows the scheme of ECDM with a rotating electrode (ECDM-RE). During machining, the rotating tool-electrode is set at the depth of cut $g_{0}$, while the workpiece moves with a feed rate $V_{f}$. In ECDM-RE process, the machining region is established in two zones: EC with electrochemical dissolution and electrical discharge zone ED. Electrical discharges in ED zone can be created by electrical 
breakdown of the vapor-gas layer as well as by instantaneous short-circuits between the electrodes. In both cases, the decisive factor is the appearance of vapor-gas layers resulting mainly by heating of the electrolyte to the boiling point. Uneven boiling of the electrolyte causes, that, the dimensions of both zones EC and ED fluctuate [6].
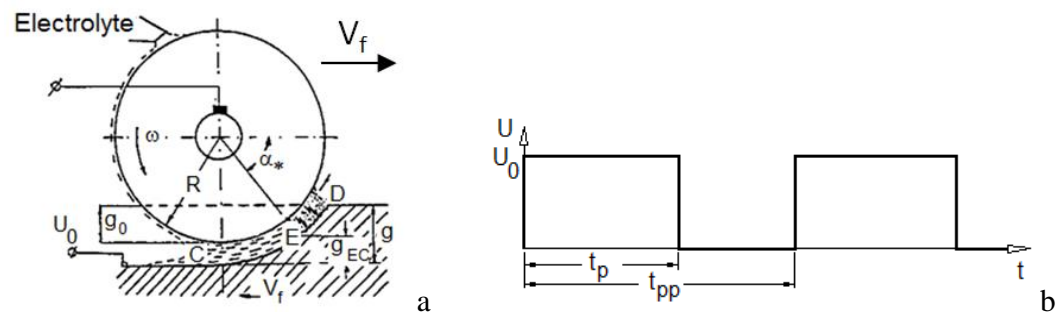

Figure 5. Scheme of ECDM: process using rotating tool electrode (a) interelectrode gap voltage pulses (b) [6]

Due to the effect of electrical erosions on the machining surface, a large number of craters are formed in ED zone. These surface irregularities are subject of electrochemical smoothing by dissolution in the EC zone and roughness is reduced. Therefore better quality of machined surface and simultaneously larger MRR in ECDM-RE than in ECM-RE or EDM are obtained.

\subsection{EXPERIMENT SETUP}

Experiments of ECDM machining of composite materials were carried out using 3 axes $\mathrm{CNC}$-electrochemical machine equipped with rotating tool head - grinding unit. Irregularities of spindle rotating movement were in the range of $\pm 10 \mu \mathrm{m}$. As the AC motor was connected to the frequency converter, it was possible to control smoothly rotating speed from 100 up to $7000 \mathrm{rpm}$. For the ECDM process For the needs of ECDM process, original power supplier of the ECM system was exchanged with the specially designed for this process, by Otto von Guericke University in Magdeburg, energy source. The process energy source is a current supply (fixed adjustable current) with controllable/adjustable limited voltage (voltage supply). It enables following parameter setup: working / pulse current (0-50 A); interelectrode voltage (20-99 V); pulse ON/OFF time (10-2000 $\mu$ s).

For the experiments cooper disc electrode with outer diameter of $100 \mathrm{~mm}$ and thickness of $3 \mathrm{~mm}$ was used. Process kinematics were as shown in Figure 5a. Experiments were carried out for BNDCC and DDCC composite materials. As the electrolyte 3\% water solution of $\mathrm{NaCl}$ was used.

\subsection{RESULTS OF ECDM MACHINING PROCESS}

Comparing to conventional grinding process, the MRR was increased by $\sim 10$ times: from $0,23 \mathrm{~mm}^{3} / \mathrm{min}$ (in case of conventional grinding) to $2,3 \mathrm{~mm}^{3} / \mathrm{min}$ (in case of ECDM process). As the ECDM process was used for machining of grooves of $2 \mathrm{~mm}$ depth (with single pass depth of 0,5 mm) in DDCC and BNDCC samples, important factor was shape of the groove after machining. Width of the grooves was measured on the bottom surface and top of the groove. Averaged values are presented in Figure 6b, whilst dimensions of working part of copper disc are presented in Figure 6a. 
a)

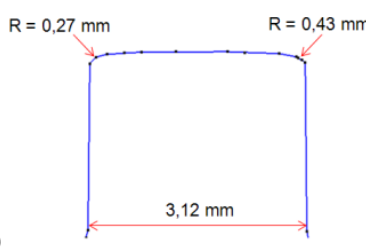

b)

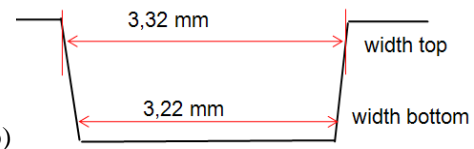

Figure 6. Geometry of grinding wheel used for ECDM machining of composite materials (a) geometry of grove machined in DDCC material $\left(\mathrm{U}-\mathrm{E}=30 \mathrm{VDC}, \mathrm{V}_{\mathrm{f}}=1 \mathrm{~mm} / \mathrm{min}\right)$ (b)

Results of ECDM machining of DDCC composite are presented in Table 4. In each case, current cut-off was set at $30 \mathrm{~A}$. Process was run with constant electrode feed of $\mathrm{V}_{\mathrm{f}}=1 \mathrm{~mm} / \mathrm{min}$ with single cut of $0,5 \mathrm{~mm}$ depth.

Table 4. Results of ECDM machining of DDCC

\begin{tabular}{|c|c|c|c|c|c|}
\hline \multirow{2}{*}{$\mathrm{U}[\mathrm{V}]$} & \multirow{2}{*}{ Pulse ON / OFF $[\mu \mathrm{s}]$} & \multicolumn{2}{|c|}{ Groove width $[\mu \mathrm{m}]$} & \multicolumn{2}{c|}{$\begin{array}{c}\text { Groove surface } \\
\text { roughness }[\mu \mathrm{m}]\end{array}$} \\
\cline { 3 - 6 } & & Bottom & top & $\mathrm{R}_{\mathrm{a}}$ & $\mathrm{R}_{\mathrm{z}}$ \\
\hline 30 & $40 / 40$ & 3.22 & 3.32 & 1.32 & 6.92 \\
\hline 30 & $200 / 200$ & 3.25 & 3.41 & 1.44 & 8.25 \\
\hline 30 & $40 / 120$ & 3.18 & 3.25 & 1.31 & 7.15 \\
\hline 50 & $40 / 40$ & 3.26 & 3.34 & 1.35 & 7.22 \\
\hline 50 & $200 / 200$ & 3.33 & 3.43 & 1.43 & 8.14 \\
\hline 50 & $40 / 120$ & 3.22 & 3.27 & 1.36 & 7.48 \\
\hline 70 & $40 / 40$ & 3.32 & 3.40 & 1.36 & 7.53 \\
\hline 70 & $200 / 200$ & 3.45 & 3.56 & 1.47 & 8.22 \\
\hline 70 & $40 / 120$ & 3.28 & 3.36 & 1.39 & 7.67 \\
\hline 90 & $40 / 40$ & 3.38 & 3.45 & 1.42 & 7.52 \\
\hline 90 & $200 / 200$ & 3.48 & 3.61 & 1.49 & 8.34 \\
\hline 90 & $40 / 120$ & 3.34 & 3.45 & 1.41 & 7.25 \\
\hline
\end{tabular}

In Figures 7 and 8 are shown surfaces of machined groove and influence of the process on the surface layer. It can be observed on the SEM micrographs of machined surfaces that ECDM process does not influence the surface in the negative way. Although there are visible some cracks on the surface after machining (Fig. 7), they are of very small depth (not exceeding $20 \mu \mathrm{m})$ - as can be observed in Figure 8.
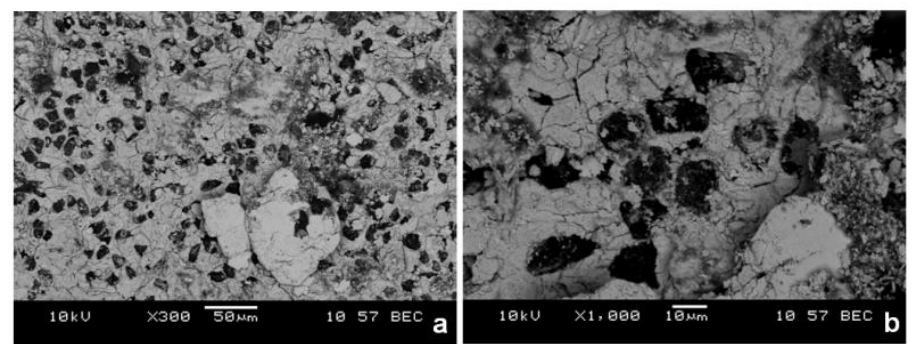

Figure 7. Surface of machined groove in DDCC composite (a - magnification 300x and b-magnification 1000x) (U$\mathrm{E}=30 \mathrm{VDC}$, Pulse ON/OFF times $40 / 40 \mu \mathrm{s}, \mathrm{V}_{\mathrm{f}}=1 \mathrm{~mm} / \mathrm{min}$ ) 

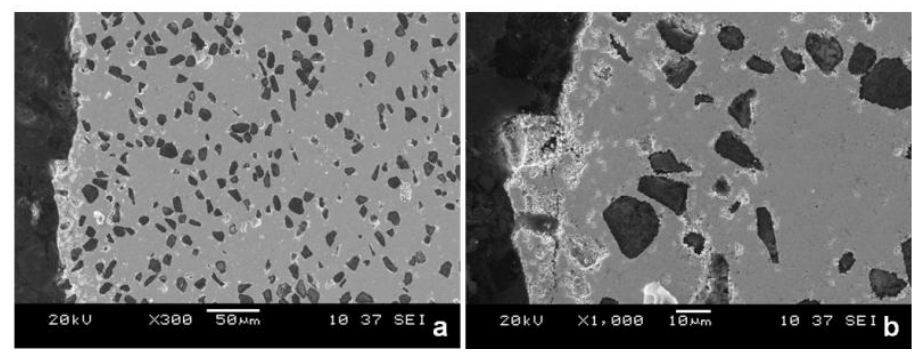

Figure 8. Cross section of machined groove in DDCC composite (a - magnification 300x and $\mathrm{b}-$ magnification $1000 \mathrm{x}$ ) (U-E $=30 \mathrm{VDC}$, Pulse ON/OFF times $40 / 40 \mu \mathrm{s}, \mathrm{V}_{\mathrm{f}}=1 \mathrm{~mm} / \mathrm{min}$ ) (b)

\subsection{RESULTS OF ECDM MACHINING PROCESS - DISCUSSION}

Experiments were performed for both composite materials (BDNCC and DDCC). In both cases achieved results were similar. It results from the fact, that ECDM process belong to the group of non-contact machining methods. As both composites have the similar bonding phase (cemented carbide) and similar grain size of 6-12 $\mu \mathrm{m}$ the dissolution and material removal process refers mainly to the bonding, conductive phase of cemented carbide.

Analyzing the results presented in Table 4, the influence of voltage and long pulse ON times on machining accuracy and surface roughness can be observed. It results from the bigger share of electrochemical dissolution - with higher interelectrode voltage applied, the groove width increases significantly. Increase of surface roughness in case of application of higher voltage and longer pulse ON times results from the fact of faster dissolution of bonding phase - abrasive, non-conducting grains are exposed.

\section{CONCLUSIONS}

Basing on the results of performed investigations it can be stated that for the effective and high precision machining of composite materials for cutting tools, combination of various machining methods might be very effective. In case of pure cemented carbide samples, conventional grinding is very useful method, enabling precise machining of cutting tools application of additional process is not necessary. Also when shaping BNDCC composite, grinding process with diamond grinding wheels (with newly developed bonding) is effective process even for removal of relatively high volumes of material (up to $1 \mathrm{~mm}$ ). In this case, as diamond grains from grinding wheel are harder than cBN grains of composite material, grinding wheel is not worn very fast and grinding process is effective for shaping composites. When it comes to machining DDCC composite it will be useful to perform rough machining (with large volume of material to be removed) with hybrid, ECDM method, and use grinding process for finishing $(\sim 0,1 \mathrm{~mm})$ operations.

Presented works were supported by the National Centre for Research and Development in Poland under Applied Research Programme, Grant No.: PBS1/A5/7/2012. 


\section{LITERATURE}

[1] ROSIŃSKI M., MICHALSKI A .: WCCo / cBN composites produced by pulse plasma sintering method, Journal of Materials Science, vol. 47, no 20, pp. 7064-7071, 2012, DOI 10.1007 / s10853-012-x.

[2] STANIEWICZ-BRUDNIK B., BACZEK E., WILK W., SKRABALAK G.: Nowe spoiwa ceramiczne do ściernic supertwardych przeznaczonych do obróbki narzędzi kompozytowych $i$ z DDCC $i$ BNDCC, XXXVI Naukowa Szkoła Obróbki Ściernej NSOS Rzeszów 2013, s. 369-376. [dysk CD - Mechanik, 2013, R. 86, nr 89].

[3] STANIEWICZ-BRUDNIK B., BACZEK E., WILK W., SKRABALAK G.: Właściwości fizyczne nowych dedykowanych spoiw ceramicznych do ściernic supertwardych przeznaczonych do obróbki narzędzi kompozytowych z DDCC i BNDCC, Innovative Manufacturing Technology 2013, Kraków. IZTW. 2013, 119 127.

[4] MCGEOUGH, J. A., KHAYRY, A. U., MUNRO, W.: Theoretical and experimental Investigation of the Relative Effects of Spark Erosion and Electrochemical Dissolution in Electrochemical Arc Machining. Annals of the CIRP, 32/1 (1983),113-116.

[5] DAVYDOV, A.D., KOZAK, J.: Physico-Chemical Principles of Electrochemical Discharge Machining. Elektronnaja Obrabotka Materialov, Surface Engineering and Applied Electrochemistry edit.USA), 3 (1991), 3 13.

[6] KOZAK, J., RAJURKAR, K.P.: Investigation of Electrochemical Arc machining with Rotating Electrode. Proceedings of the ISEM-10, Magdeburg, 1989, 498-509. 